\title{
Serum miR-210 as a potential biomarker of early clear cell renal cell carcinoma
}

\author{
HIDETO IWAMOTO $^{1}$, YUSUKE KANDA ${ }^{2}$, TAKEHIRO SEJIMA ${ }^{1}$, MITSUHIKO OSAKI ${ }^{2}$, \\ FUTOSHI OKADA ${ }^{2}$ and ATSUSHI TAKENAKA ${ }^{1}$
}

Departments of ${ }^{1}$ Surgery, Division of Urology and ${ }^{2}$ Biomedical Sciences, Division of Pathological Biochemistry, Faculty of Medicine, Tottori University, Tottori 683-8503, Japan

Received June 7, 2013; Accepted July 19, 2013

DOI: 10.3892/ijo.2013.2169

\begin{abstract}
Early detection and treatment are critical in the management of renal cell carcinoma (RCC). However, there is no standard serum biomarker to facilitate early diagnosis or prognostic stratification in patients with RCC. Recent reports suggest that circulating microRNAs (miRNAs) have great potential as biomarkers for diagnosis and prognosis in patients with several types of cancers. Further, many studies using miRNA microarray analysis demonstrated that miR-210 expression in clear cell carcinoma (CCC), which is the largest subtype of RCC, was significantly upregulated in tumor tissue. Therefore, we investigated whether serum miR-210 could be a useful biomarker for the diagnosis and progression of CCC. This study included 34 CCC patients and 23 healthy controls (HC). First, we analyzed tissue miR-210 levels in tumor tissues and matched normal tissues from the $34 \mathrm{CCC}$ patients. Second, we investigated the serum miR-210 levels in the $34 \mathrm{CCC}$ patients and the $23 \mathrm{HC}$ patients. Real-time polymerase chain reaction (PCR) was used to measure miRNA levels. Moreover, we examined the correlation between serum miR-210 levels and the clinicopathological parameters. Among patients with CCC, expression of miR-210 was higher in tumor tissues compared to normal tissues $(\mathrm{P}<0.001)$. Serum miR-210 levels were higher in CCC patients compared to HCs $(\mathrm{P}=0.001)$. Receiver operating characteristic (ROC) curve analysis showed an area under the ROC curve (AUC) of 0.77 (95\% confidence interval, 0.65-0.89) and a sensitivity and specificity of 65 and $83 \%$, respectively. In addition, there was no significant association between serum miR-210 levels and age, sex, tumor size or existence of metastasis at diagnosis among the $34 \mathrm{CCC}$ patients. In conclusion, serum miR-210 upregulation
\end{abstract}

Correspondence to: Dr Mitsuhiko Osaki, Department of Biomedical Sciences, Division of Pathological Biochemistry, Faculty of Medicine, Tottori University, 86 Nishi-cho, Yonago, Tottori 683-8503, Japan E-mail: osamitsu@med.tottori-u.ac.jp

Key words: microRNA, miR-210, renal cell carcinoma, clear cell carcinoma, serum biomarker, early diagnosis may occur in the early stage of CCC and serum miR-210 can be a useful biomarker for early CCC in humans.

\section{Introduction}

Renal cell carcinoma (RCC) is a common urological neoplasm of the adult kidney. The diagnostic modalities and therapeutic techniques for RCC continue to improve and the overall incidence and mortality of RCC has increased in the last 20 years (1). The 5-year survival rate is $\sim 98 \%$ for stage I disease and $\sim 50 \%$ for stage III disease (2), which underscore the importance of early detection and treatment of RCC. However, early detection of often difficult, because early-stage renal tumors are often asymptomatic and non-palpable. Therefore, the identification of non-invasive biomarkers for early-stage RCC would be of benefit. However, no accurate biomarker for RCC currently exists (3).

Recent studies suggest that microRNAs (miRNAs), which are non-protein-coding small RNAs, are involved in cancer progression and metastasis. MicroRNAs are 22 nucleotides in length and regulate gene expression at the post-transcriptional level by binding to the untranslated region (3'UTR) of target mRNAs, leading to translational inhibition and/or mRNA degradation (4). Specific expression profiles of miRNAs in tissue have been reported in a variety of cancers, including RCC (5). Early studies suggested that miRNAs were strictly intracellular molecules, but more recent studies suggest that miRNAs are highly stable and abundant in the serum, urine and other body fluids. This is because exosomes likely protect miRNAs against degradation by RNase $(6,7)$. Interestingly, serum miRNA levels are similar in men and women and do not vary with patient age (8).

Thus, circulating miRNAs might be good non-invasive biomarkers for diagnostic and prognostic considerations in a variety of cancers. Indeed, several studies have reported that specific circulating miRNAs were useful for distinguishing patients with cancer (e.g., colorectal cancer, breast cancer, prostate cancer) from healthy controls (HCs) $(6,9,10)$. However, the number of studies regarding circulating miRNAs in patients with RCC is small.

Several studies using miRNA microarray analysis demonstrated that miR-210 expression in clear cell carcinoma (CCC), which is the largest subtype of RCC, was significantly 
upregulated in tumor tissues and cell lines (11). In addition, some groups reported that miR-210 upregulation played an important role in tumorigenesis in various types of human cancers $(12,13)$.

The goal of this study was to determine whether circulating miR-210 was a useful diagnostic biomarker for distinguishing CCC patients from HCs.

\section{Materials and methods}

Patients and sample collection. The study was approved by the ethics committee of Tottori University Hospital, Japan and all the patients provided written informed consent. We prospectively collected tissue and serum samples from patients undergoing radical nephrectomy or nephron-sparing surgery for renal tumors. Sample collection was performed between 2011 and 2013 at the Department of Urology, Tottori University Hospital. Thirty-four patients with histologically confirmed CCC and $23 \mathrm{HCs}$ with no previous history of any cancer were included in this analysis. Detailed clinicopathological parameters of patients are summarized in Table I.

Tissue samples were obtained from tumor tissues and matched normal tissues from the same kidney specimen in patients with CCC. Immediately after resection, tissue samples were frozen in liquid nitrogen and stored at $-80^{\circ} \mathrm{C}$.

Blood samples were obtained prior to surgery. Serum was separated after centrifugation (3,000 rpm, $10 \mathrm{~min})$ and stored at $-80^{\circ} \mathrm{C}$.

Total RNA isolation. Total RNA was extracted from tissue using the mirVana ${ }^{\mathrm{TM}}$ miRNA isolation kit (Ambion, USA) and from $200 \mu \mathrm{l}$ of serum using the microRNA extractor SP kit (Wako, Japan) according to the manufacturer's recommendation (final elution volume, $50 \mu \mathrm{l}$ ). RNA quantity and purity were determined using a NanoDrop Spectrophotometer ND-1000 (Thermo Scientific, USA). The RNA samples were stored at $-80^{\circ} \mathrm{C}$ until reverse transcription (RT) reaction.

Quantitative real-time PCR. Complementary DNA (cDNA) was synthetized from total RNA using the TaqMan MicroRNA RT kit (Applied Biosystems) and using miRNA-specific RT primers from the TaqMan MicroRNA assay (Applied Biosystems). RT reaction mixtures were incubated for $30 \mathrm{~min}$ at $16^{\circ} \mathrm{C}, 30 \mathrm{~min}$ at $42^{\circ} \mathrm{C}, 5 \mathrm{~min}$ at $85^{\circ} \mathrm{C}$ and then held at $4^{\circ} \mathrm{C}$. Quantitative real-time PCR was performed using the TaqMan MicroRNA assay on the ABI PRISM 7900HT system (Applied Biosystems). All experiments were performed as specified in the manufacturer's protocols.

Statistical methods. Analysis of the real-time PCR data was done using SDS software, version 2.4 (Applied Biosystems). MicroRNA levels in tissue were normalized against miR-145 and microRNA levels in serum were normalized against miR-16. We confirmed that the expression of miR-145 in tissue and miR-16 in serum were not significantly different when comparing patients and HCs. The relative expression levels of miR-210 were determined by the equation: $2^{-\Delta \mathrm{CT}}$

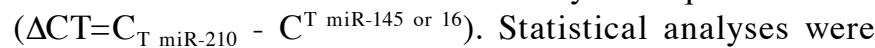
performed using PASW statistics 18 (SPSS, Chicago, IL,
Table I. Clinicopathological parameters.

\begin{tabular}{lcc}
\hline & \multicolumn{2}{c}{ Serum samples } \\
\cline { 2 - 3 } & CCC (n=34) & HC (n=23) \\
\hline Sex & & \\
Male & 26 & 11 \\
Female & 8 & 12 \\
Age (years) & & \\
Mean & 66.5 & 53.5 \\
Range & $29-86$ & $36-84$ \\
Pathological stage & & \\
pT1a & 17 & - \\
pT1b & 8 & - \\
pT2a & 3 & - \\
pT2b & 1 & - \\
pT3a & 4 & - \\
pT3b & 1 & - \\
pT4 & 0 & - \\
Lymph nodes metastasis & 24 & - \\
Distant metastasis & 5 & - \\
Grade & & \\
G1 & & \\
G2 & & \\
G3 & & \\
\hline
\end{tabular}

USA). Sensitivity, specificity and area under curve (AUC) for serum microRNA levels were determined using receiver operator characteristic (ROC) analysis. The relationship between clinicopathologic parameters and microRNA levels was examined using the Mann-Whitney U or Kruskal-Wallis test, as appropriate. P-values of $<0.05$ were considered to represent statistical significance.

\section{Results}

Validation in tissue samples. Using real-time PCR, we first assessed tissue miR-210 levels normalized against miR-145 in 34 pairs of tumor tissues and matched normal tissues obtained from patients with CCC. Tissue miR-210 levels were significantly higher in tumor tissues than in normal tissues $(\mathrm{P}<0.001$; Fig. 1A). There was no difference in the CT values for miR-145 when comparing tumor tissues and normal tissues $(\mathrm{P}=0.236$; Fig. 1B). In 31 cases (92\%), the miR-210 level in tumor tissues was increased by $>2$-fold when compared with that in normal tissues.

Validation in serum samples. We assessed serum miR-210 levels normalized against miR-16 in $34 \mathrm{CCC}$ patients and 23 HCs. The 34 serum samples from CCC patients perfectly matched up with tissue samples described above. Serum miR-210 levels were significantly higher in CCC patients than in $\mathrm{HCs}(\mathrm{P}=0.001$; Fig. 2A). There was no significant difference 
A

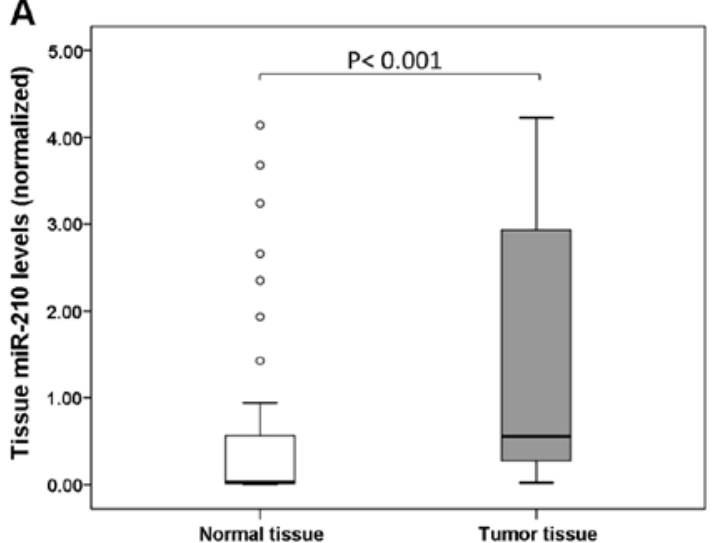

B

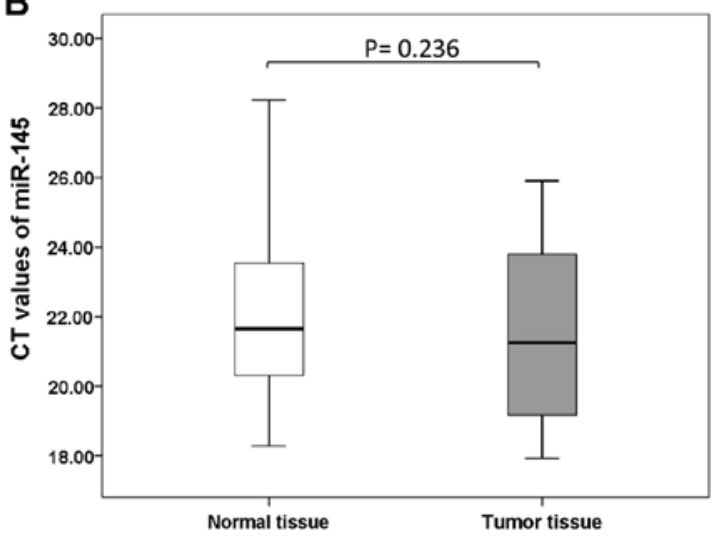

Figure 1. (A) Tissue miR-210 levels normalized against miR-145 in 34 pairs of tumor tissues and matched normal tissues taken from patients with clear cell carcinoma (CCC). The tissue miR-210 levels were significantly higher in tumor tissues than in normal tissues $(\mathrm{P}<0.001)$. (B) There was no significant differences in CT values of miR-145 when comparing tumor tissues and matched normal tissues.
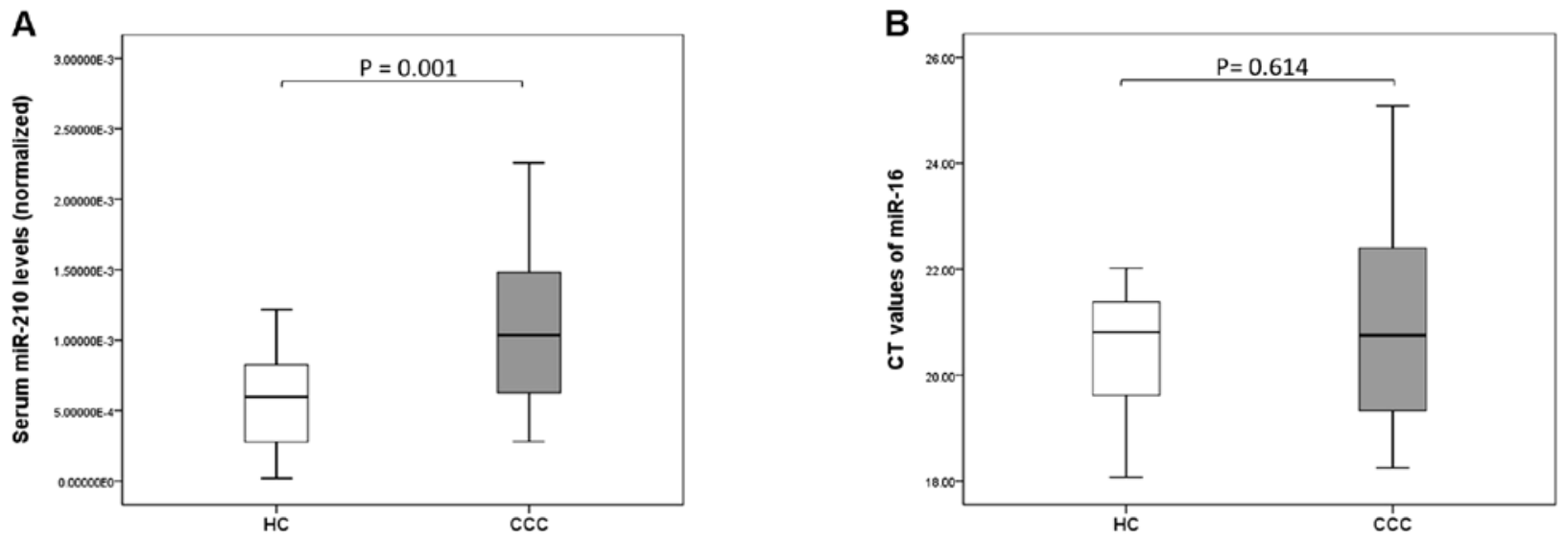

Figure 2. (A) Serum miR-210 levels normalized against miR-16 in 34 CCC patients and in 23 healthy controls (HCs). Serum miR-210 levels were significantly higher in CCC patients than in HCs $(\mathrm{P}=0.001)$. (B) There was no significant difference in CT values of miR-16 when comparing CCC patients and HCs.

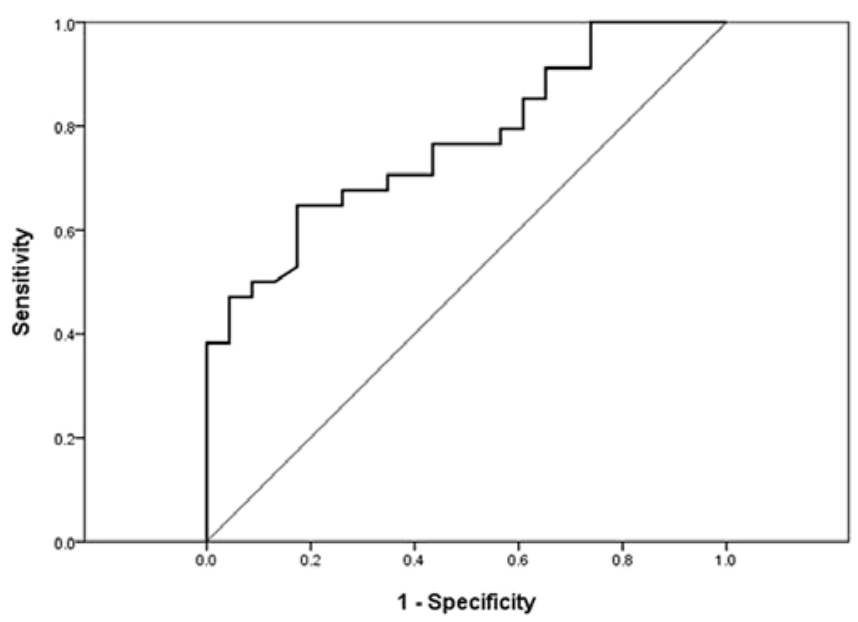

Figure 3. Receiver operating characteristic (ROC) analysis of serum miR-210 showed an area under the ROC curve (AUC) of 0.77 (95\% confidence interval, $0.65-0.89)$ with a sensitivity and specificity of 65 and $83 \%$, respectively.

in the CT values of miR-16 when comparing $\mathrm{CCC}$ patients and HCs $(\mathrm{P}=0.614$; Fig. 2B).
ROC curve analysis indicated that the serum miR-210 level might serve as a useful biomarker for differentiating patients with CCC from those with HCs; the AUC was 0.77 (95\% confidence interval, 0.65-0.89) and the sensitivity and specificity was 65 and $83 \%$, respectively (Fig. 3).

We analyzed the relationship between serum miR-210 levels and clinicopathological parameters. There was no significant association between serum miR-210 levels and age, sex, tumor size, or existence of metastasis at diagnosis (Fig. 4). Although serum miR-210 level tended to be higher in patients with metastasis at diagnosis when compared with patients without metastasis ( $\mathrm{P}=0.067$; Fig. 4D), this difference did not reach the level of statistical significance.

\section{Discussion}

Previous studies have described the potential use of circulating microRNA as a non-invasive biomarker for various cancers [e.g., miR-29a and miR-92 in colorectal cancer (9); miR-195 in breast cancer (14); miR-17-5p, miR-21, miR-106a and miR-106b in gastric cancer (15); and miR-141 and miR-26a in prostate cancer $(6,16)]$. In the case of RCC, several recent 
A

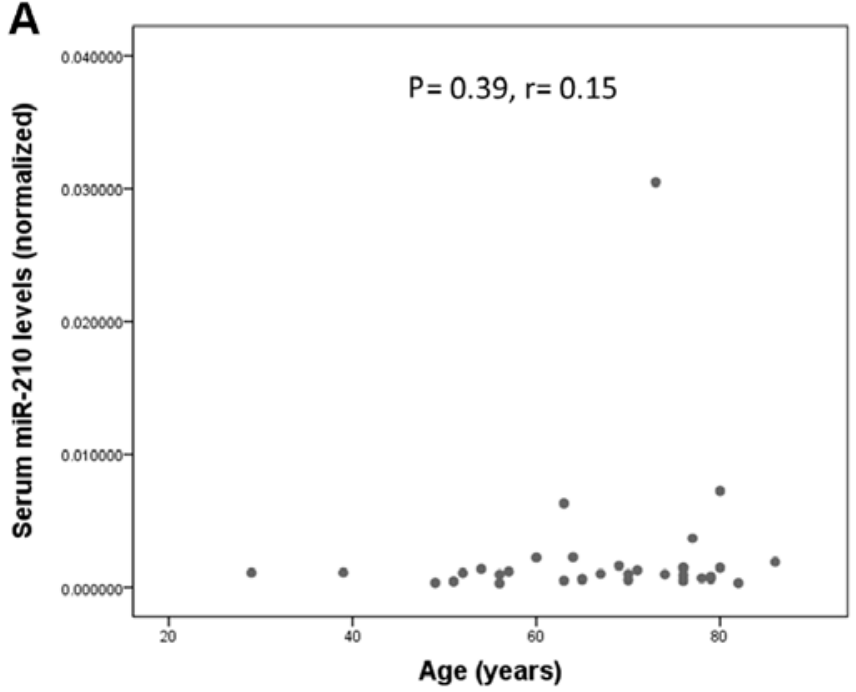

C

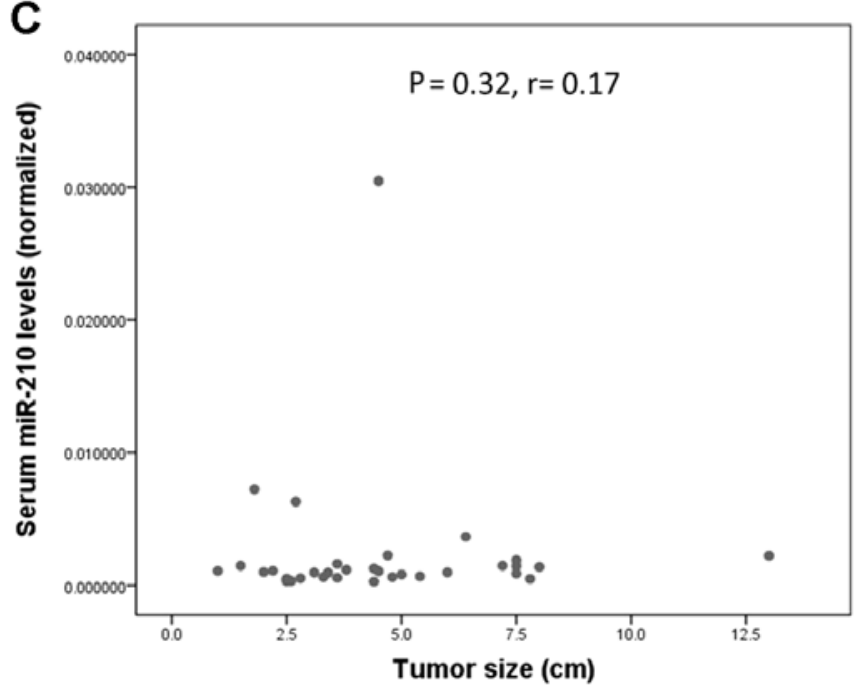

B

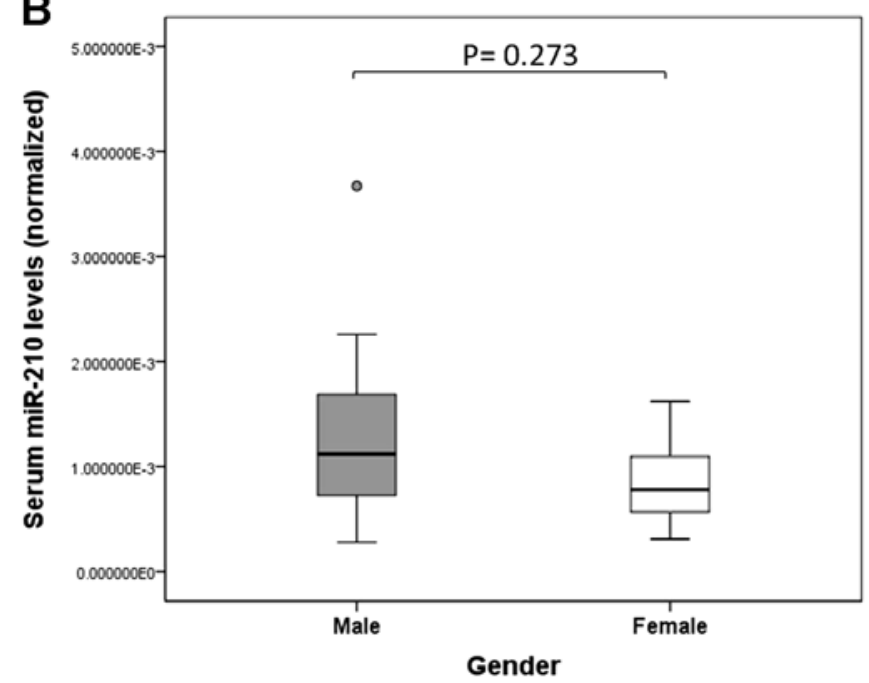

D

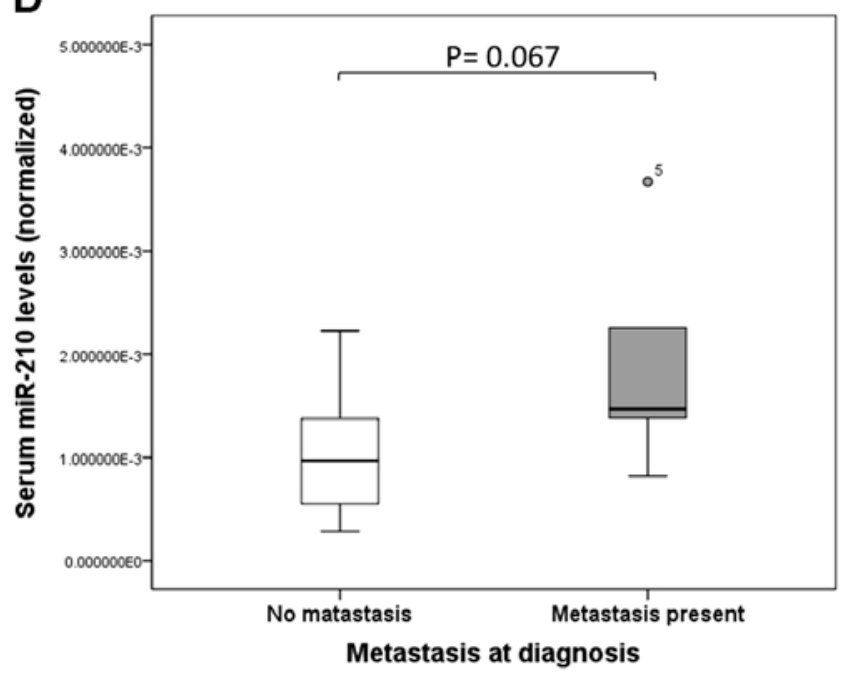

Figure 4. Analysis of the correlation between serum miR-210 levels and clinicopathological parameters. There was no significant association between serum miR-210 levels and age (A), gender (B), tumor size (C), or existence of metastasis at diagnosis (D).

A

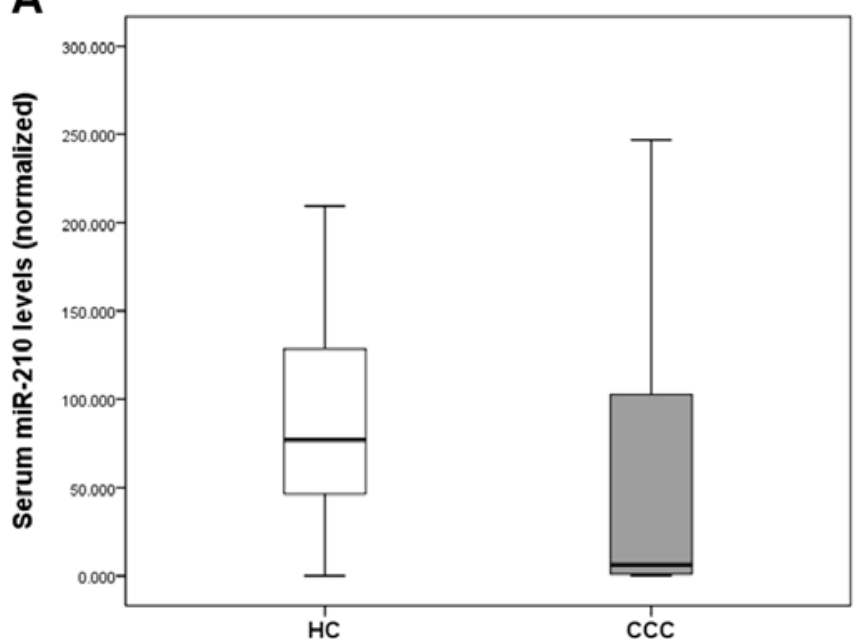

B

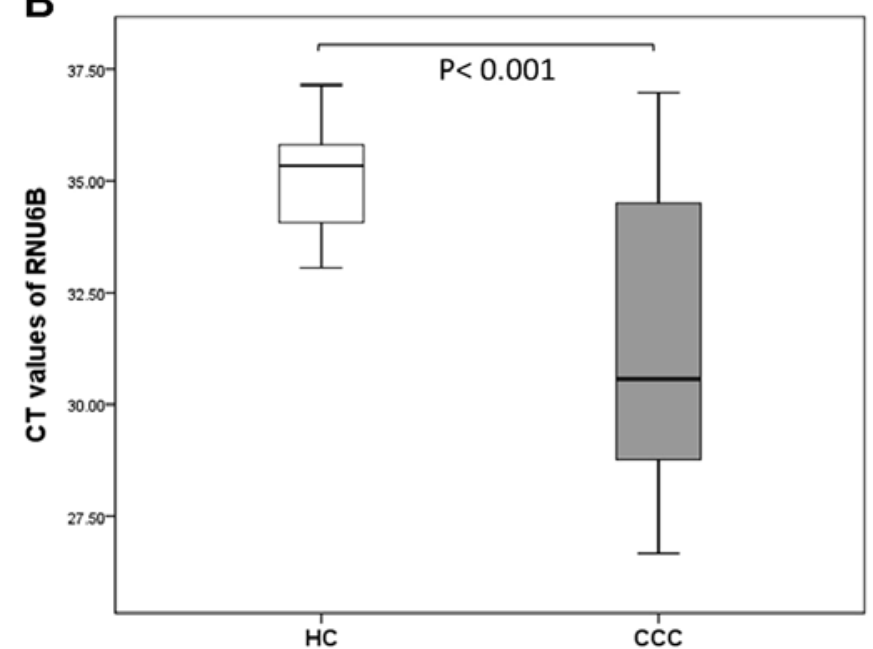

Figure 5. (A) There were no significant differences in serum miR-210 levels normalized against RNU6B when comparing 34 CCC patients and 23 HCs. (B) CT values of miR-16 in 34 CCC patients and in 23 HCs. CT values of RNU6B were significantly lower in CCC patients than in HCs (P<0.001). Moreover, there was marked variability of the $\mathrm{Ct}$ values when comparing $\mathrm{CCC}$ patients and $\mathrm{HCs}$. 
studies using miRNA microarray analysis showed different microRNA expression profiles when comparing tumor tissues and matched normal tissues. However, some of the data regarding the number and type of up-/downregulated microRNAs is conflicting (17-19). Regardless, several recent studies have described the use of circulating microRNA as a new biomarker for RCC.

The present study showed that serum miR-210 levels were significantly higher in CCC patients than in HCs. Furthermore, there was no correlation between serum miR-210 levels and clinicopathological parameters. These results indicate that upregulation of serum miR-210 may occur in the early stage of $\mathrm{CCC}$ and can serve as a potential biomarker of early diagnosis in $\mathrm{CCC}$.

Four studies have investigated the utility of circulating microRNAs as a diagnostic biomarker for RCC. Wulfken et al were the first to report that the serum miR-1233 level was increased in 84 patients with RCC from a multicenter cohort (AUC, 0.588; sensitivity, 77.4\%; specificity, 37.6\%). Moreover, they investigated 13 samples from patients with angiomyolipoma or oncocytoma whose serum miR-1233 levels were similar to those of patients with RCC (20). Redova et al also demonstrated that serum miR-378 and miR-451 were potential biomarkers for RCC. When the utility of miR-378 and miR-451 was evaluated in an independent cohort of 90 patients with RCC and $35 \mathrm{HCs}$, the combination of serum miR-378 and miR-451 enabled identification of RCC with relatively high accuracy rate (AUC 0.86; sensitivity, 81\%; specificity, 83\%) (21). Hauser et al confirmed that serum miR-378 was significantly increased in 25 CCC patients $(\mathrm{P}=0.006)$, but they did not detect a difference in the level of this biomarker when comparing 117 patients with RCC versus $123 \mathrm{HCs}$ (22). Zhao et al reported that tissue miR-210 levels in 33 CCC patients were significantly higher in tumor tissue than in adjacent non-tumoral renal parenchyma $(\mathrm{P}=0.004)$. Serum miR-210 levels were also significantly higher in $68 \mathrm{CCC}$ patients than in $42 \mathrm{HCs}(\mathrm{P}<0.001)$ (AUC, 0.87; sensitivity, $81.0 \%$; specificity, $79.4 \%$ ). Furthermore, serum miR-210 levels in patients with $\mathrm{CCC}$ decreased by 1 week after surgical resection of the tumor (23).

The present study normalized the assessed RNA values in tissue and serum against those of miR-145 and miR-16, respectively, which is a different approach from that used by Zhao et al. There is no consensus regarding the optimal normalization gene to use for quantitative real-time polymerase chain reaction (qRT-PCR) analysis of circulating mRNAs (24). The present study did not utilize RNU6B or 5s rRNA for normalization of qRT-PCR data because some studies have reported that RNU6B and 5s rRNA were not stable in human tissues or body fluids. In their study targeting serum miRNA in gastric cancer patients, Song et al demonstrated that RNU6B could not be detected in almost half of the serum samples; in the other half of patients, it was detected with $\mathrm{Ct}$ values of $>40$. Moreover, RNU6B was less stably expressed than let-7a and miR-16 in normal and cancerous human solid tissues (25). Although we actually examined the same study using RNU6B for normalization, there was marked variation in $\mathrm{Ct}$ values when comparing CCC patients and HCs (Fig. 5). Therefore, we selected other miRNAs (miR-16, miR-103a, miR-122 and miR-145) for the purposes of normalization, based on previous reports $(21,26)$. Then, we determined which of these miRNAs was expressed in similar amounts when comparing CCC patients and HCs. As a result of these investigations, miR-145 and miR-16 were selected for use as normalizing genes in the present study.

MiR-210 is upregulated in various types of human cancers, suggesting its important role in tumorigenesis (27). Jung et al reported that plasma miR-210 levels in human breast cancer were associated with trastuzumab sensitivity, tumor presence and lymph node metastasis (28). Although the mechanism of upregulation of miR-210 is still unclear, some groups have reported that miR-210 is induced under-hypoxic conditions via hypoxia-inducible factors (HIFs) in various cancer cell lines (28). It is well known that HIF1 $\alpha$ and HIF $2 \alpha$ accumulate in CCC as a result of abrogated ubiquitin-mediated degradation due to loss or deficiency of the von Hippel-Lindau tumor suppressor (VHL) tumor suppressor gene (29). Nakada et al demonstrated that miR-210 was highly expressed in RCC cell lines and that its expression clearly correlated with the accumulation of hypoxia-inducible factor $1 \alpha$ (HIF1 $\alpha)$ under normoxia as well as under hypoxia, suggesting that miR-210 upregulation in CCC was most likely due to accumulation of HIF1 $\alpha$. Further, they confirmed that restoration of VHL expression in the VHL-deficient cell line led to the degradation of HIF1 $\alpha$ and suppressed the expression of miR-210, suggesting that miR-210 expression is regulated via the VHL-HIF1 $\alpha$ pathway (11). Since VHL inactivation is observed in $>70 \%$ of CCC patients, its inactivation may occur in the early stage of tumorigenesis. This raises the possibility that the expression of miR-210 is upregulated and plays a role in the early stage of tumorigenesis in CCC tissue and that serum miR-210 is upregulated in the human peripheral blood in the early stages of CCC.

For these reasons, serum miR-210, which can be easily measured on an outpatient basis, could be a useful biomarker for early diagnosis and facilitate earlier treatment and, hence, improves outcomes. Further studies with a larger number of patients are warranted to validate these results.

In conclusion, early detection and treatment of RCC is critical to improve outcomes. Serum miR-210 is a useful biomarker for early CCC.

\section{References}

1. Hollingsworth JM, Miller DC, Daignault S and Hollenbeck BK: Rising incidence of small renal masses: a need to reassess treatment effect. J Natl Cancer Inst 98: 1331-1334, 2006.

2. Devita VT Jr, Hellman S and Rosenberg SA: Cancer Principles and Practice of Oncology. 8th edition, Lippincott Williams \& Wilkins, 2008.

3. Ljungberg B, Cowan NC, Hanbury DC, Hora M, Kuczyk MA, Merseburger AS, Patard JJ, Mulders PF, Sinescu IC; European Association of Urology Guideline Group: EAU guidelines on renal cell carcinoma: the 2010 update. Eur Urol 58: 398-406, 2010.

4. Slaby O, Jancovicova J, Lakomy R, Svoboda M, Poprach A, Fabian P, Kren L, Michalek $J$ and Vyzula R: Expression of miRNA-106b in conventional renal cell carcinoma is a potential marker for prediction of early metastasis after nephrectomy. J Exp Clin Cancer Res 29: 90, 2010.

5. Volinia S, Calin GA, Liu CG, Ambs S, Cimmino A, Petrocca F, Visone R, Iorio M, Roldo C, Ferracin M, Prueitt RL, Yanaihara N, Lanza G, Scarpa A, Vecchione A, Negrini M, Harris CC and Croce CM: A microRNA expression signature of human solid tumors defines cancer gene targets. Proc Natl Acad Sci USA 103: 2257-2261, 2006. 
6. Mitchell PS, Parkin RK, Kroh EM, Fritz BR, Wyman SK, Pogosova-Agadjanyan EL, Peterson A, Noteboom J, O'Briant KC, Allen A, Lin DW, Urban N, Drescher CW, Knudsen BS, Stirewalt DL, Gentleman R, Vessella RL, Nelson PS, Martin DB and Tewari M: Circulating microRNAs as stable blood-based markers for cancer detection. Proc Natl Acad Sci USA 105: 10513-10518, 2008.

7. Chim SS, Shing TK, Hung EC, Leung TY, Lau TK, Chiu RW and Lo YM: Detection and characterization of placental microRNAs in maternal plasma. Clin Chem 54: 482-490, 2008.

8. Hunter MP, Ismail N, Zhang X, Aguda BD, Lee EJ, Yu L, Xiao T, Schafer J, Lee ML, Schmittgen TD, Nana-Sinkam SP, Jarjoura D and Marsh CB: Detection of microRNA expression in human peripheral blood microvesicles. PLoS One 3: e3694, 2008.

9. Huang Z, Huang D, Ni S, Peng Z, Sheng W and Du X: Plasma microRNAs are promising novel biomarkers for early detection of colorectal cancer. Int J Cancer 127: 118-126, 2010.

10. Roth C, Rack B, Müller V,Janni W,Pantel K and Schwarzenbach H: Circulating microRNAs as blood-based markers for patients with primary and metastatic breast cancer. Breast Cancer Res 12 : R90, 2010.

11. Nakada C, Tsukamoto Y, Matsuura K, Nguyen TL, Hijiya N, Uchida T, Sato F, Mimata H, Seto $M$ and Moriyama $M$ Overexpression of miR-210, a downstream target of HIF1 $\alpha$, causes centrosome amplification in renal carcinoma cells. J Pathol 224: 280-288, 2011.

12. Crosby ME, Kulshreshtha R, Ivan M and Glazer PM: MicroRNA regulation of DNA repair gene expression in hypoxic stress. Cancer Res 69: 1221-1229, 2009.

13. Fasanaro P, D'Alessandra Y, Di Stefano V, Melchionna R, Romani S, Pompilio G, Capogrossi MC and Martelli F: MicroRNA-210 modulates endothelial cell response to hypoxia and inhibits the receptor tyrosine kinase ligand Ephrin-A3. J Biol Chem 283: 15878-15883, 2008.

14. Heneghan HM, Miller N, Lowery AJ, Sweeney KJ, Newell J and Kerin MJ: Circulating microRNAs as novel minimally invasive biomarkers for breast cancer. Ann Surg 251: 499-505, 2010.

15. Tsujiura M, Ichikawa D, Komatsu S, Shiozaki A, Takeshita H Kosuga T, Konishi H, Morimura R, Deguchi K, Fujiwara H, Okamoto K and Otsuji E: Circulating microRNAs in plasma of patients with gastric cancers. Br J Cancer 102: 1174-1179, 2010.

16. Mahn R, Heukamp LC, Rogenhofer S, von Ruecker A, Müller SC and Ellinger J: Circulating microRNAs (miRNA) in serum of patients with prostate cancer. Urology 77: 1265.e9-16, 2011.

17. Redova M, Svoboda M and Slaby O: MicroRNAs and their target gene networks in renal cell carcinoma. Biochem Biophys Res Commun 405: 153-156, 2011.

18. White NM, Bao TT, Grigull J, Youssef YM, Girgis A, Diamandis M, Fatoohi E, Metias M, Honey RJ, Stewart R, Pace KT, Bjarnason GA and Yousef GM: miRNA profiling for clear cell renal cell carcinoma: biomarker discovery and identification of potential controls and consequences of miRNA dysregulation. J Urol 186: 1077-1083, 2011.
19. Wotschofsky Z, Busch J, Jung M, Kempkensteffen C, Weikert S, Schaser KD, Melcher I, Kilic E, Miller K, Kristiansen G, Erbersdobler A and Jung K: Diagnostic and prognostic potential of differentially expressed miRNAs between metastatic and nonmetastatic renal cell carcinoma at the time of nephrectomy. Clin Chim Acta 416: 5-10, 2013.

20. Wulfken LM, Moritz R, Ohlmann C, Holdenrieder S, Jung V, Becker F, Herrmann E, Walgenbach-Brünagel G, von Ruecker A, Müller SC and Ellinger J: MicroRNAs in renal cell carcinoma: diagnostic implications of serum miR-1233 levels. PLoS One 6: e25787, 2011.

21. Redova M, Poprach A, Nekvindova J, Iliev R, Radova L, Lakomy R, Svoboda M, Vyzula R and Slaby O: Circulating miR-378 and miR-451 in serum are potential biomarkers for renal cell carcinoma. J Transl Med 10: 55, 2012.

22. Hauser S, Wulfken LM, Holdenrieder S, Moritz R, Ohlmann CH, Jung V, Becker F, Herrmann E, Walgenbach-Brünagel $G$, von Ruecker A, Müller SC and Ellinger J: Analysis of serum microRNAs (miR-26a-2*, miR-191, miR-337-3p and miR-378) as potential biomarkers in renal cell carcinoma. Cancer Epidemiol 36: 391-394, 2012.

23. Zhao A,Li G, Péoc'h M, Genin C and Gigante M: Serum miR-210 as a novel biomarker for molecular diagnosis of clear cell renal cell carcinoma. Exp Mol Pathol 94: 115-120, 2013.

24. Kroh EM, Parkin RK, Mitchell PS and Tewari M: Analysis of circulating microRNA biomarkers in plasma and serum using quantitative reverse transcription-PCR (qRT-PCR). Methods 50: 298-301, 2010.

25. Song J, Bai Z, Han W, Zhang J, Meng H, Bi J, Ma X, Han S and Zhang Z: Identification of suitable reference genes for qPCR analysis of serum microRNA in gastric cancer patients. Dig Dis Sci 57: 897-904, 2012.

26. Cheng Y, Wang X, Yang J, Duan X, Yao Y, Shi X, Chen Z, Fan Z, Liu X, Qin S, Tang $X$ and Zhang C: A translational study of urine miRNAs in acute myocardial infarction. J Mol Cell Cardiol 53: 668-676, 2012.

27. Camps C, Buffa FM, Colella S, Moore J, Sotiriou C, Sheldon H, Harris AL, Gleadle JM and Ragoussis J: hsa-miR-210 is induced by hypoxia and is an independent prognostic factor in breast cancer. Clin Cancer Res 14: 1340-1348, 2008.

28. Jung EJ, Santarpia L, Kim J, Esteva FJ, Moretti E, Buzdar AU, Di Leo A, Le XF, Bast RC Jr, Park ST, Pusztai L and Calin GA: Plasma microRNA 210 levels correlate with sensitivity to trastuzumab and tumor presence in breast cancer patients. Cancer 118: 2603-2614, 2012.

29. Eble JN, Sauter G, Epstein JI and Sesterhenn IA (eds.): World Health Organization Classification of Tumours. Pathology and Genetics of Tumours of the Urinary System and Male Genital Organs. IARC Press, Lyon, pp9-87, 2004. 